\title{
CONTRIBUTION OF VALUE ADDED HUMAN CAPITAL TO EMPLOYEE PRODUCTIVITY IN CRAFT CREATIVE INDUSTRY OF TASIKMALAYA
}

\author{
Lina Marlina*), Maman Sulaeman, A Mundzir \\ Polytechnic of Triguna Tasikmalaya \\ marlinatsm@gmail.com
}

\begin{abstract}
The creative industry is the focus of government to boost economic growth in recent decades. Creative industry is the utilization of talent, ideas, and creativity in generating creativity and creative power of individuals. Craft creative industry (kriya) sub-sector as a typical product of Tasikmalaya become focus of the researcher. The population of workers in the creative industries is dominated by high school graduates. It's interesting to measure the added value and productivity. This study aims to measure the contribution and influence of value added human capital (VAHU) on emplyee productivity (EP). VAHU is one component of the value added inlellectual coefficient (VAIC) Method developed by Pulic. The study focuses on VAHU because the research sphere is related to the workforce. The results of the study are expected to help creative industry entrepreneurs and decision makers to make policies related to a competent labor supply program. This research uses quantitative descriptive analysis with primary and secondary data. Documentation is taken from company reports recorded in the industry and trade offices in Tasikmalaya for the last six years. Random sampling includes the creative industries of embroidery craft, footwear, furniture, batik, and mendong (wicker). The results showed that the footwear craft industry reached the highest VAHU and the lowest mendong industry. The highest EP is seen in the embroidery industry and the lowest furniture industry. While compliance between variables in this study showed that $V A H U$ no significant effect on EP.
\end{abstract}

Key Words: Value Added Human Capital, Value Added Inlellectual Coefficient, Productivity, Education

\section{INTRODUCTION}

Economic growth and welfare of society is one of Indonesia's national goals. Government policy in 2009-2025 is a policy that emphasizes the industrial sector. Currently the utilization of creativity and innovation through technology is more highlighted than to judge a product only from raw materials or production systems. This economic concept is called the creative economy

The creative economy was started by Landry and Bianchini 1995 in The Creative City in London, then in 2000, Landry through his book The Creative City: A Toolkit for Urban Innovator, conveys ideas to inspire stakeholders for developing culturaleconomic. According to United 
Kingdom (UK) creative industries as "as those industries which their origin in individual creativity, skill and talent, and which have a potential for wealth and job creation through the generation and exploration of intellectual property and content", (Creative Industries Mapping Document, DCMS, 2001).

In Indonesia the creative economy begins with the Presidential Instruction No. 6 of 2009 on Creative Economic Development and the Blueprint of Indonesia Creative Economy 2009-2025. According to data from Bekraf (2015) Gross Domestic Product (GDP) of Indonesia's creative economy 2015 grew by $4.38 \%$. GDP of 2014 amounted to 784.82 trillion to 852.24 trillion in 2015 , meaning that the creative economy contributes $7.38 \%$ to the total national economy. As for sustainable growth, the government targets the contribution of GDP of Creative Economy in 2019 to reach 7$7.5 \%$, and foreign exchange is targeted to reach $6.5-8 \%$ (CNN Indonesia, 2015). The target set by the government, although it looks real but still needs hard work so that the government's expectations exceed the target set.

There are 16 sub-sectors of creative economy in Indonesia based on contribution to the national economy in sequence are culinary, fashion, craft, tv and radio, publishing, architecture, applications and game developers, advertising, music, photography, performing arts, product design, art, interior design, film and visual communication design. Creative industry sub-sector is still dominated by culinary, fashion and craft. Since long, Tasikmalaya is famous for kriya (craft) city so this research is focused on the craft sub-sector as a typical industry of Tasikmalaya. Kriya (craft) in creative industry is defined as art seen from its material covering all craft made of metal, wood, leather, textile, leather, glass, kramik and textile (www.bekraf.co.id). The availability of abundant raw materials and the creativity of industry actors has become the advancement of this subsector.

National economic growth rests on labor productivity. Released by Bekraf 2015, the problem of creative industry sector of labor productivity of Indonesia is still dominated by middle education worker. Meanwhile, according to Becker's 1993 theory, the level of education affects the productivity of work and income of a person who will accumulate on economic growth. This means that the high level of education will affect a person's ability to produce something. The following is Indonesia's creative economy labor data:

Table 1.1

Creative Economy Workers 2015

\begin{tabular}{ccc}
\hline Education & Indonesian workers & $\begin{array}{c}\text { Manpower creative } \\
\text { economy }\end{array}$ \\
\hline SMP to lower & $62,30 \%$ & $36,10 \%$ \\
\hline High School \& Equal & $26,69 \%$ & $57,20 \%$ \\
\hline Upward diploma & $11,01 \%$ & $6,70 \%$ \\
\hline
\end{tabular}

Source: Bekraf, 2015 
The dominance of the creative industry by the Blue Collar workforce, which consists of sales force, service personnel, production personnel, and manual workers, makes the researcher interested to measure the contribution of labor (human capital) which in fact is educated this medium to the special productivity in creative craft industry of Tasikmalaya

Human capital is a component of intellectual capital in addition to other components, namely structural capital and relational capital. Intellectual capital developed by Pulic 1998, known as Value Added Intellectual Coefficient (VAIC) Method. This method is used to measure the company in producing added value. This research is focused on human capital considering the role of human capital in giving value and advancing the company. The factors of production required in the form of money, machine, materials, methods, market, and management won't be optimal if the factor 'man' as human capital isn't qualified. According to Becker's 1993 theory, saying that education, training, health, migration, and other information will determine productivity. While the productivity of labor is related to the comparison of how much output is generated by the input of labor that process.

This research aims to measure the value added human capital (VAHU) and its contribution to the productivity of labor or employee productivity (PE) in the creative industries of the craft sub-sector in Tasikmalaya. The results of the research can be used as the acts of management of creative industry players in the recruitment and development of labor, as well as the policy makers in government in preparing the skilled labor supply program.
The empirical research on human capital and productivity has often been done mainly in the banking industry sector. The results of his research varied. The result, there is a positive effect and some studies show the results don't affect between these variables, as has been done by Malik and Aslam (2012), Al Musali and $\mathrm{Ku}$ Ismail (2014), Ermawati, Noch, Zakaria (2017), Ririn Satya (2013), Chen, and Lin (2003), Chen, Cheng, and Hwang (2005). Not consistent results of previous studies into reference researchers to prove themselves the focus of this study.

The difference with previous research is that earlier research is more widespread in the three components of intellectual capital and the banking industry. While the researchers here only focus with the human capital and creative industries in the craft sub-sector in Tasikmalaya.

Based on the explanation, the researcher took the title "Contribution of Value Added Human Capital to Employee Productivity in Craft Tasikmalaya Creative Industry".

\section{LITERATURE REVIEW}

\subsection{Human Capital}

The concept of human capital continues to develop, Gerry S Becker (1993) explains that man isn't just a resource but is a capital that results in returns and any expenditures made in order to develop the quality and quantity of capital is an investment activity. Furthermore, JacFitenz (2009), Human capital can be described as a combination of factors: (a) The personality traits he brings in from birth to work, intelligence, energy, generally positive attitude, reability, commitment. 
(b) A person's ability to learn, talent, imagination, creativity, and what is often referred to as street smart. (c) A person's motivation to share information and knowledge, team spirit and goal orientation. So human capital is a union of talents, knowledge, skills and competencies in individuals that can be used to perform activities so as to increase a value.

The development of concepts and methods to measure the contribution of human capital more and more along with the dynamics of the company in the face of business opposition. Pulic, 1998 in his study did not directly measure the company's intellectual capital, but proposed a measure to assess the efficiency of value added as a result of the company's Value Added Intellectual Coefficient (VAIC). Human capital (VAHU) is one of the main components of VAIC whose measurement is based on the value of the efficiency of the added value resulting from the intellectual capabilities of its human resources (Ulum: 2007). VAIC method is used to measure how big the efficiency of the three components of human capital, relation capital and structural capital in generating corporate value. Because this research focuses only on human capital, then that will be calculated only related to labor. Measurement begins by looking at the company's ability to generate value added (VA) and then looking for value added human capital (VAHU).

Calculating Value Added (VA)

$$
\text { VA = Output- Input }
$$

Output : total sales and other revenue Inputs : sales expenses and other expenses (other than personnel expenses)
Calculating VAHU

VAHU $=$ Value Added Human Capital

VAHU : VA ratio to $\mathrm{HC}$

VA : Value Added

HC : Employee expenses

The higher the value of VAHU, the greater the contribution of employees to the company means employees work efficiently.

\subsection{Productivity}

Productivity is a way of assessing the effectiveness and efficiency of business processes in a company. The amount of benefits a company will show how efficient the resources used. The result of productivity assessment is a ratio between effectiveness as output and efficiency as input. In this case the performance index measurement is done to measure objectively the level of achievement (Sarjono, 2001).

Several factors that affect productivity include process, labor, product, quality or quality. Because in this study focused on labor, then the productivity to be calculated is labor productivity.

The ratio used to calculate labor productivity (Employee Productivity / $\mathrm{EP})$ as:

Employee Productivity $=\frac{\text { Output }}{\text { Input }}$
Employee
EP : output ratio to input
Output : total production produced
IE : Total employees in the
company

\subsection{Research Hypothesis}

$\mathrm{H}_{0}=$ No influence of VAHU on EP.

$\mathrm{Ha}=\mathrm{VAHU}$ influence on the EP 
The terms of acceptance and rejection are as follows:

If the value of Sig < Probability 0.05 means there is VAHU influence on the EP

If the value of Sig > Probability 0.05 means there is no influence of VAHU on EP

\section{RESEARCH METHOD}

The population of this research is all creative industries of Tasikmalaya craft which is registered at Industry and Trade Office (Disperindag) 2010-2015. Sampling technique in this research use purposive sampling method. Purposive sampling is a technique of sampling with particular consideration or withdrawal of a particular purposed sample (Noch: 2012). Types and data sources used in this study are primary data and secondary data. Data collection was obtained from interviews with business actors and documentation studies through the report of embroidery, footwear, furniture, batik and mendong industry companies registered in Disperindag during 20102015.

The research technique used quantitative analysis technique, done by quantifying the research data so as to produce the information needed in the analysis. The analytical tool uses linear regression to estimate the power of the relationship. The scale used is the ratio and nominal scale appropriate for the measurement using linear regression analysis assisted with SPSS 20.

\section{RESULT AND DISCUSSION}

Here's the calculation of the average value added human capital using the formula:

\begin{tabular}{|c|}
\hline VAHU $=\underline{\text { Value Added }}$ \\
\hline Human Capital \\
\hline
\end{tabular}

Table 1.2

Mean of Valuation Result of VAHU Craft 2010-2015 (In Thousand Rupiah)

\begin{tabular}{lrrrrr}
\hline & \multicolumn{1}{c}{ Output } & \multicolumn{1}{c}{ Input } & \multicolumn{1}{c}{ VA } & \multicolumn{1}{c}{ HC } & VAHU \\
\hline Embroidery & $64,891,783.33$ & $15,037,575.00$ & $49,854,208.33$ & $10,447,021.67$ & 4.86 \\
\hline Footwear & $14,485,653.33$ & $1,086,250.00$ & $13,399,403.33$ & $2,356,738.50$ & 5.46 \\
\hline Furniture & $2,290,941.67$ & $212,500.00$ & $2,078,441.67$ & $403,773.50$ & 5.21 \\
\hline Batik & $4,927,626.93$ & $1,306,762.67$ & $3,620,864.27$ & $781,694.81$ & 4.65 \\
\hline Mendong & $3,575,155.67$ & $1,115,205.33$ & $2,459,950.33$ & $535,768.28$ & 4.37 \\
\hline
\end{tabular}

Source : Data processed 2017

The table above shows the average VAHU for Craft Embroidery for six consecutive years obtained from the calculation of 2010 of $4.85,2011$ amounted to $4.08,2012$ of $5.77,2013$ of $4.18,2014$ of 4.88 , and 2015 of 5.40 , the highest increase occurred in 2012. The average is seen in Table 1.2 on average of 4.86. This shows that every Rp 1.00 invested by the company produces a return value of $\mathrm{Rp} 4.86$.

VAHU for Craft Footwear for six consecutive years is obtained from the calculation of 2010 of $6.16,2011$ of $5.88,2012$ of $5.38,2013$ of 5.312014 of 5.15 and 2015 of 4.89 , the highest increase occurred in 2010. Average visible in table 1.2 average of 5.46. This 
shows that every Rp 1.00 invested by the company produces a return value of Rp 5.46.

VAHU for Craft Furniture for six consecutive years is obtained from the calculation of 2010 of $4.54,2011$ amounted to 5.59, 2012 of 5.63, 2013 of 5.372014 of 5.02 and 2015 of 5.12, the highest increase occurred in 2012. The average seen in table 1.2 average of 5.21. This shows that every $\mathrm{Rp} 1.00$ invested by the company produces a return value of $\mathrm{Rp} 5.21$.

VAHU for Craft Batik for six consecutive years obtained from the calculation of 2010 amounted to 4.66, 2011 amounted to $4.43,2012$ of 4.55 , 2013 of 4.092014 of 4.73 and 2015 of 5.44 , the highest increase occurred in 2015. The average seen in the table 1.2 average of 4.65. This shows that every $\mathrm{Rp} 1.00$ invested by the company produces a return value of $\mathrm{Rp} 4.65$.

VAHU for Craft Mendong for six consecutive years was obtained from the calculation of 2010 of $1.89,2011$ amounted to $3.79,2012$ of $5.65,2013$ of 5.56, 2014 of 4.83 and 2015 of 4.47, the highest increase occurred in 2012. Average visible in table 1.2 average of 4.37. This shows that every $\mathrm{Rp} 1.00$ invested by the company produces a return value of $\mathrm{Rp} 4.37$.

Average return on employee investment to fluctuating companies from 2010 to 2015, from the highest average VAHU earned by VAHU Craft Footwear of 5.46 and the lowest obtained by VAHU craft Mendong 4.37.
These values are the added value that every employee can give to the company. The calculation of value added human capital shows how much value the company generates with the funds the company has spent on labor to see the contribution that employees can give each rupiah that has been invested in human capital to value added.

From the calculation of VAHU can be seen that the craft of footwear get the highest score and this corresponds to the interviewee of some informants that the workforce most often do the training of footwear and meetings with communities from outside the Tasikmalaya region. These community meetings and trainings generate new experiences and new information. Unlike the woven Craft mendong which is getting here the fewer fans mendong. Consumers mendong switch to buyers of plastic mats are more simple and more portable. So that producers mendong more that closed his business and affect the value of output and input associated with VAHU calculations.

Here's the calculation of the average employee productivity by using the formula:

\begin{tabular}{|l|} 
Employee Productivity $=\frac{\text { Output }}{\text { Input }}$ \\
Employee
\end{tabular}

Employee productivity shows how labor contributes financially to the amount of net income of the craft industry in Tasikmalaya. 
Table 1.3

Mean of Valuation Result of EP Craft 2010-2015

(In Thous and Rupiah)

\begin{tabular}{lrrr}
\hline & Net Income & Employee & EP \\
\hline Embroidery & $39,407,186.67$ & 353 & $109,766.18$ \\
\hline Footwear & $11,042,664.83$ & 144 & $72,127.17$ \\
\hline Furniture & $1,674,668.17$ & 28 & $60,754.26$ \\
\hline Batik & $2,839,169.46$ & 38 & $96,653.40$ \\
\hline Mendong & $1,924,182.06$ & 31 & $63,821.43$ \\
\hline
\end{tabular}

Source : Data processed 2017

Based on the above table average EP for embroidery craft for six consecutive years obtained from the calculation of 2010 of $105,357,2011$ amounted to 143,207, 2012 of 154,749, 2013 of $107.183,2014$ of 71.957 , and 2015 of 76.145 , the highest increase occurred in 2012. Seen in table 1.3 average of $109,766.18$ this shows that the workforce contributed financially to the company of Rp 109,766.18.

EP for footwear crafts for six consecutive years was obtained from the 2010 calculation of 84.866, 2011 amounted to 84.566, 2012 of 70.768 , 2013 of $30.182,2014$ of 93.169 , and 2015 of 69.213 , the highest increase occurred in 2014. Seen in table 1.3 average of $72,127.17$ this shows that the workforce gives financial contribution to the company of Rp 72,127.17.

EP for furniture craft for six consecutive years was obtained from the 2010 calculation of $23,831,2011$ amounted to 47,623, 2012 of 45,600, 2013 of $27,205,2014$ of 173,325 , and 2015 of 46,942, the highest increase occurred in 2014. Seen in table 1.3 on average, $60,754,26$ it shows that the workforce gives financial contribution to the company of Rp 60,754,26.

EP for batik craft for six consecutive years obtained from the calculation of 2010 amounted to
185,996, 2011 amounted to 55.835, 2012 of $48.053,2013$ by $62.102,2014$ of 157.464 , and 2015 of 70.470 , the highest increase occurred in 2014. Seen in the table 1.3 average of $96,653.40$ this shows that the workforce contributes finance to the company of $\operatorname{Rp} 96,653.40$. EP for the craft of mendong for six consecutive years obtained from the calculation of 2010 of $15.420,2011$ amounted to $68,081,2012$ of 64.340 , 2013 of 43.226, 2014 of 133.349 , and 2015 of 58.512, the highest increase occurred in 2012. Seen in the table 1.3 average of 63.821 .43 this indicates that the workforce gives financial contribution to the company of $\mathrm{Rp}$ 63,821,43.

Factors that cause the fluctuation of employee productivity is the total net income and the number of employees, craft industry that shows high productivity obtained by the embroidery industry with a value of Rp 109.766.18 and the lowest obtained by the furniture industry with a value of $\mathrm{Rp}$ $60,754,26$. So the company should be more focused in increasing the competent workforce in increasing the increase of company's sales productivity. The higher the value of the rupiah given the workforce in the company shows that the better the 
worker productivity means more efficiently.

According to interviews with some business actors and workers that the craft embroidery has a strong brand, and have its own customers. Orders are many in the area even from abroad so the amount of sales is high. Embroidery is related to fashion that turnover quickly adapted to the fashions and trends of his day. While the durable furniture competition, the competition is very tight with the existence of plastic factory products are lightweight, and cheap. This makes the circulation of furniture sales very slow and requires the optimization of creativity and innovation to produce unique products.

Table 1.4

Coefficient Calculation Result Coefficients $^{\mathrm{a}}$

\begin{tabular}{|c|c|c|c|c|c|c|}
\hline \multirow{2}{*}{\multicolumn{2}{|c|}{ Model }} & \multicolumn{2}{|c|}{ Unstandardized Coefficients } & \multirow{2}{*}{$\begin{array}{c}\text { Standardized } \\
\text { Coefficients } \\
\text { Beta }\end{array}$} & \multirow[t]{2}{*}{$\mathrm{t}$} & \multirow[t]{2}{*}{ Sig. } \\
\hline & & B & Std. Error & & & \\
\hline \multirow{2}{*}{1} & (Constant) & 54968,552 & 52107,262 & \multirow[b]{2}{*}{,094 } & 1,055 & ,300 \\
\hline & VAHU & 5225,596 & 10473,025 & & ,499 & 622 \\
\hline
\end{tabular}

a. Dependent Variable: PE

Based on the table above coefficients obtained regression equation $\mathrm{Y}=54968,552+5225,596 \mathrm{X}$. It appears that if the value of VAHU does not exist then the constant value of labor productivity is 54968,552 and each addition of $1 \%$ VAHU level then the productivity will increase by 5225,596 . The regression coefficient shows the plus number indicates that the VAHU has a positive effect on the EP. In accordance with the proposed hypothesis that:

$\mathrm{H}_{0}=$ No influence of VAHU on EP. $\mathrm{H}_{\mathrm{a}}=\mathrm{VAHU}$ influence on the EP.

And the terms of acceptance and rejection stipulated that:
If the value of $\mathrm{Sig}<$ Probability 0.05 means there is VAHU influence on the EP

If the value of Sig > Probability 0.05 means there is no influence of VAHU on EP

The result shows a significant value of 0.622 and greater than 0.05 or $(0.622>$

0.05 ) so it is concluded VAHU does not affect the EP meaning $\mathrm{H}_{0}$ accepted and $\mathrm{H}_{\mathrm{a}}$ rejected.

Comparing the $t_{\text {count }}$ and $t_{\text {table }}$ values with the provision if, If $t_{\text {count }}>$ of $t_{\text {table }}$ then there is a VAHU with respect to EP and If $t_{\text {count }}<t_{\text {table }}$ then there is no VAHU to EP. Obtained tcount is 0,499 and $\mathrm{t}_{\text {table }} 2.048(\mathrm{df}=30-2)$ then $0,449<$ 2,048 , that is because $t_{\text {count }}$ is smaller than $\mathrm{t}_{\text {table, }}$, so it is concluded that $\mathrm{H}_{0}$ is accepted and $\mathrm{H}_{\mathrm{a}}$ is rejected, it means there is no influence of VAHU on EP. 
Table 1.5

Summary Model

\begin{tabular}{|c|c|c|c|c|}
\hline Model & $\mathrm{R}$ & $\mathrm{R}$ Square & $\begin{array}{c}\text { Adjusted R } \\
\text { Square }\end{array}$ & $\begin{array}{c}\text { Std. Error of } \\
\text { the Estimate }\end{array}$ \\
\hline 1 &, $094^{\mathrm{a}}$ &, 009 &,- 027 & 46232,08467 \\
\hline
\end{tabular}

Based on the table Model Summary R Square value of 0.009 means that the influence of VAHU to EP only influential $0.09 \%$ and the results do not reach $1 \%$. while $99.1 \% \mathrm{EP}$ is influenced by other variables not examined in this study.

Table 1.6

Summary of Statistics Calculations

\begin{tabular}{cccccc}
\hline $\begin{array}{c}\text { Influence } \\
\text { between variables }\end{array}$ & R Square & $\mathbf{T}_{\text {count }}$ & $\mathbf{t}_{\text {table }}$ & Sig. & Test result \\
\hline Xto Y & 0,009 & 0,499 & 2,048 & 0,622 & $\mathrm{H}_{0}$ accepted \\
\hline
\end{tabular}

Source: results data processing 2017 with SPSS 20.00

Based on the summary table of statistical calculations that the level of compliance, $t$ calculation, the level of significance shows that $\mathrm{H}_{0}$ accepted and $\mathrm{H}_{\mathrm{a}}$ rejected, ie no significant influence between VAHU on EP. VAHU only affect the EP of $0.009 \%$ or $1 \%$ and the remaining $99 \%$ influenced by other variables that are not researched.

The results of this study are similar to those done by Kartika and Hartane (2013) that VAHU has no significant effect on profitability. Muhammad Amin Ismail (2009) that human capital is not significant, negatively related to profitability and ROA. Previous studies have shown that other variables that affect labor productivity are not only seen from human capital but relation capital and structural capital.

The results of this study contradict the findings of research conducted by Aggrey, Niringiye (2010), Human capital investment increases labor productivity in manufacturing companies in Africa. George Chouliarakisac and Monica Correa -
Lopez $^{\text {ba }}$ (2009). The occurrence of a catch-up effect on labor productivity. The results of the study, Spain is able to pursue labor productivity such as England.

Becker's 1993 analysis revealed that human capital assumes schools can increase income and productivity. Education can provide knowledge, skills, and problem-solving skills. However, many deny that schools provide an alternative to increasing productivity. Basically education conveys information about the ability, perseverance, and other valuable properties of a person. Another opinion that Mankiw said in 2006, that human capital is the capital needed by the company obtained through education or training (on the job training) to support work experience. Because according to Mankiw the factors that determine productivity include physical capital, human capital, natural resources and technological knowledge of workers.

Analysis of these experts related to this research, found that the beginning of the problem faced by creative 
industries in Tasikmalaya craft is the majority of creative workforce craft of middle to lower education. The results of the study that their educational background proved only $1 \%$ affect on labor productivity, in other words compliance it exists, but not significant. Middle to high school background only contributes little to the productivity of its workforce. Most likely if creative workforce education is upgraded to higher levels will make a greater contribution to productivity. This will be in line with the analysis of experts that the level of education affects the productivity of a person in producing something.

Human capital is needed to support the ability to produce goods or services and increase productivity through labor education. People who have higher levels of education will be able to have better jobs and wages than low-educated people. If salary or income reflects productivity, the higher a person's education the higher the productivity and able to contribute economic growth.

However, the insignificant influence in this study may be possible for the following reasons: First, theoretically the diminishing marginal physical productivity factor, ie the addition of labor input to the production process will cause an increase in output. However, the output will decrease as more labor inputs are added. Factor diminishing marginal physical productivity applies to short-term production functions. This gap can be finalized by first formulating the workforce to be recruited in production. So that income and labor input predictions become balanced. Secondly, it is related to the empirical that found no significant influence related to the majority of creative industry workforce is still not highly educated ie the majority of middle-educated workers so that productivity is not optimal. The results of this study, in line with Chen and Lin (2003) stated the expenditure of companies in improving human resources is an investment in human capital. So the higher a person's education will increase the ability of workers and able to produce more goods and services, ultimately increasing productivity and income.

Based on this finding, cooperation between entrepreneurs and decision makers is needed in the procurement of labor. The management company needs to do a better and better educated workforce to improve productivity. Decision-makers in this case the government needs to take a policy to create programs that support the craft creative industry entrepreneurs in providing targeted training. In addition, there needs to be a community network for creative industries business actors to gain new knowledge so as to create innovation. The decision makers are able to provide containers as information marketing jejajaring to boost sales. So the more networks available the easier it will be for creative industry entrepreneurs to market their products and increase sales. Increased sales will be directly proportional to the number of goods produced, resulting in higher labor productivity.

\section{CONCLUSION}

The research results can be drawn some conclusions conclusions as follows:

1. The calculation of value added human capital shows that the Tasikmalaya craft industry in the last six years, the highest added 
value of human capital is obtained by the footwear craft industry and the lowest is mendong.

Value added human capital footwear gets the highest value because the workforce in the footwear sector often conducts training and knowledge transfer in community meetings. While the customer wicker craft that switch to plasik, so that more mendong craftsmen who closed his business. This affects the output and input values associated with VAHU calculations.

2. Calculation of empowee productivity shows that Tasikmalaya craft industry in the last six years, the highest productivity empoyee obtained by embroidery craft industry and the lowest obtained by furniture industry.

Employee productivity embroidery craft gets a high score because the embroidery craft has a strong brand, and have its own customers. The rapid turn of fashion every year keeps production running. While furniture is durable pruduk. customers are shifting to lightweight, cheap plastic factory products. This makes produtivitas down because of slow orders.

3. Compliance between variables in this study showed that value added

\section{REFERENCES}

Aggrey, Niringiye. (2010). Effect of Human Capital on Labor Productivity in Sub Sahara African anufacturin. Jurnal

Al. Musali, Ku. Ismail. (2014). Intellectual Capital and its effect on financial performance of banks: Evidence from Saudi Arabia. International conference human capital has no significant effect on empoyee productivity.

The results of the study that empoyees educational background proved low affect on labor productivity, in other words compliance it exists, but not significant. if creative workforce education is upgraded to higher levels will make a greater contribution to productivity.

\subsection{Suggestion}

From the above conclusions, to achieve the intent and objective of increasing employee productivity through improving the quality of human capital, it is suggested as follows:

1. Creative industry entrepreneurs to recruit some well-educated, trained and experienced workforce to increase productivity. In addition it formulates the first sales target and the number of workers who will be involved to be balanced and optimal.

2. Decision makers provide training programs and information containers in helping workers and employers improve their productivity.

3. Subsequent research used other variables such as structural capital and relational capital or human capital with control of health variables and experience to increase productivity.

on Accounting Studies 2014, ICAS 2104, Kuala Lumpur Malaysia

Ante Pulic. (1998). Measuring the Performance of intellectual Potential In knowledge Economy. Presented in 1998 at the 2nd Mc Master World Congress on Measuring 
Intellectual Capital by the Austrian Team for Intellectual Potential

Becker, S, Gerry. (1993). Human Capital. A Theoritical and AmpiricalAnalisis with Special Referene to Education 3th Edition. London: The University of Cicago Press

Chen, H.M, Lin, K.J. (2003). The Measurement of Human Capital and Its Effect On The Analysis of Financial Statements. International Journal of Management, Vol. 20, No.4

DCMS. (1998). Mapping The Creative Industries. www.culture.gov.uk

Fitz-Enz, Jac. (2009). The ROI of Human Capital. Measuring The Economic value of Employee Performance. New York: Amacom

George Chouliarakisac, Monica Correa Lopezba. (2009). Cathcing-up, then falling behind: Comparative Productivity Growth between Spain and the United kingdom, 1950-2004. Jurnal

HaryadiSarjono. (2001). Model PengukuranProduktivitasBerdas arkanPendekatanRasioOutput Per Input.Journal The Winners, Vol. 2 No. 2, September 2001: 130-136

Kartik, Hartane. (2013). Pengaruh Intellectual Capital Pada Perusahaan Perbankan Yang Terdaftar Di Bursa Efek Indonesia PadaTahun 20072012. Journal Business Accounting Review, Vol I. No 2, 2013

Landry. C,F. Bianchini. (1995). The Creative City. Demos: London

M. Y. Noch, A. Rasyid. (2012). MetodologiPenelitian: UntukManajemendanAkuntansi. Medan: Perdana Publishing
M.-C. Chen, S.-J. Cheng, and Y. Hwang. (2005). An Empirical Investigation Of The Relationship Between Intellectual Capital And Firms' Market Value And Financial Performance. Journal Of Intellectual Capital, vol. 6, pp. 159-176, 2005

Malik, Aslam. (2012). Intellectual Capital Efficiency And Corporate Performance In Developing Countries:AComparasion Between Islamic And Conventional Bank On Pakistan. Interdisciplinary Journal of Contemporary Research in Business, Vol 4. No. I, May 2012

Mankiw, Gregory. (2006).

PengantarEkonomiMakro,

EdisiKetiga. SalembaEmpat: Jakarta

Muhammad, Amin Ismail. (2009). Intellectual Capital Effisiency and Firm's Performance: Study on Malaysian Financial Sector. InterntionalJournal of Economic and Finance, Vol I. No 2, August 2009

Ririn Regiana Dwi Satya. (2013). AnalisisPengukuranProduktivita sDenganMenggunakanMetode Value Added Productivity Dan Productivity Ratio (StudiKasus Pt Asahimas Flat Glass, Tbk). JurnalFaktor Exacta, Vol. 5 No. 4: 268-282, ISSN: 1979 276x

Ulum, Ihyaul. (2007). Pengaruh Intellectual Capital TerhadapKinerjaKeuangan Perusahaan Perbankan Di Indonesia. Program PascasarjanaUniversitasDiponeg oro

Y. Ermawati, M. Y. Noch, Z. Zakaria, A.Ikhsan, and M. Khaddafi. (2017). Reconstruction of Financial Performance to 
Manage Gap between Value Added Intellectual Coefficient (VAICTM) and Value of Company in Banking Company Listed in Indonesia Stock Exchange. International Journal of Economics and Financial Issues, vol. 7, pp. 537-549

\section{Internet:}

www.bekraf.co.id

https://www.cnnindonesia.com/ekonomi I

http://www.culture.gov.uk/creative/creat ive_industries.html 